\title{
A questão do estranhamento entre a superação e o passo de volta: sobre Ontologia nos extremos
}

\author{
Matheus Correa de Sousa Heleno*
}

\author{
SARTORI, Vitor B. Ontologia nos extremos: o embate Heidegger e Lukács, uma \\ introdução. São Paulo: Intermeios, 2019, 307p.
}

Em 2019, a editora Intermeios publicou o livro Ontologia nos extremos: 0 embate Heidegger e Lukács, uma introdução, de autoria do Prof. Dr. Vitor B. Sartori, hoje vinculado aos programas de graduação e de pós-graduação do curso de Direito da Universidade Federal de Minas Gerais (UFMG). O título adveio da primeira parte da tese de doutoramento de Sartori, orientada por Jeanette Antonios Maman e defendida na Universidade de São Paulo, em 2013. Conta, também, com uma apresentação redigida por Ester Vaisman, que esboça um breve panorama acerca da questão ontológica em duas frentes, a saber: a) o itinerário de resgate dos limites e das potencialidades da subjetividade percorrido pelos filósofos modernos e b) a importância de questões ontológicas comuns entre Heidegger e Lukács, como a cotidianidade e o estranhamento, ainda que ambas encontrem resoluções extremamente díspares nos dois autores mencionados.

Ontologia nos extremos: o embate Heidegger e Lukács, uma introdução possui 307 páginas e, como o próprio autor expõe em seu prefácio, resulta de uma árdua pesquisa com cunho eminentemente marxista. Porém, não se deixa colapsar pela perspectiva mecanicista do marxismo vulgar, que compreende as formações ideais enquanto produtos passivos da tão nomeada "base material". Tampouco fetichiza o pensamento na forma de um mero exercício exegético. Ao contrário, Sartori coloca em ação aquilo que György Lukács e, posteriormente, José Chasin chamaram de crítica imanente, ou ainda de análise imanente e estrutural, cujo princípio está em tomar a bibliografia investigada como entificação concreta, isto é, como forma de ser que comporta nexos significativos próprios antes de configurar um amálgama de impressões subjetivas dos mais variados intérpretes. Assim, Sartori segue o objetivo de explicitar tanto a consistência autossignificativa dos textos por ele analisados quanto a determinação social do pensamento neles abarcada.

Dessa maneira, ao seguir o diapasão marxiano de que a filosofia, em suas mais diversas configurações, é uma formação ideológica sob a qual os indivíduos tomam consciência acerca das contradições inerentes à realidade e as levam a término ${ }^{1}$, Sartori visa demonstrar que as teorizações de Heidegger e Lukács, apesar de encontrarem gênese no solo da sociedade capitalista, não se reduzem a predicados passivos dela. Antes, colocam-se como "condição para se operar em meio à própria realidade" (SARTORI, 2019, p.13), pois uma vez gestadas em dado contexto procuram responder a ele na forma de uma tomada de posição concreta.

Por óbvio, os dois teóricos em tela tomaram posições antagônicas diante das possibilidades efetivas dispostas na sociedade capitalista do século $X X$ e, consequentemente, seus esforços ontológicos ocuparam extremos distintos nessa época. Donde se justifica o título do livro de Sartori e a necessidade de se confrontar as articulações filosóficas de Heidegger e Lukács, uma vez que apenas identificar os temas comuns a ambos os autores resultaria em uma falsa identidade entre eles. $O$ esforço verdadeiramente válido, parafraseando Marx em Crítica da filosofia do direito de Hegel, jaz na constatação da lógica específica do objeto

\footnotetext{
* Graduando em Direito/UFMG. Grupos de pesquisa "Marx como crítico do Direito e da política" e "Tinta Vermelha".

1 "As formas jurídicas, políticas, religiosas, artísticas ou filosóficas, em resumo, as formas ideológicas sob as quais os homens adquirem consciência desse conflito e o levam até o fim" (MARX, 2017, p. 50).
} 
específico e, portanto, na diferença dos caminhos e das conclusões engendradas por esses pensadores, ainda que eles tenham se debruçado sobre matérias semelhantes.

Assim, a presente resenha pretende expor as principais descobertas de Sartori, planando sobre os marcos substanciais que foram galgados pelo autor de Ontologia nos extremos: o embate Heidegger e Lukács, uma introdução. Isso, é claro, sem antecipar a leitura da obra aos interlocutores deste texto, mas, antes, explicitando a importância da pesquisa nela pronunciada.

Faz-se importante dizer, ainda, que Sartori não ignora, em seus esforços, produções teóricas pretéritas as quais lançaram luz à comparação entre as ontologias de Heidegger e Lukács. Nesse sentido figuram Lucien Goldmann e Nicolas Tertulian como precursores, mesmo que em graus distintos. Enquanto Goldmann constatou o nexo entre Heidegger e Lukács a partir das obras Ser e tempo e História e consciência de classe, inebriando-se em certo exagero que colocava o primeiro desses livros no status de resposta aos escritos lukácsianos de 1923, Tertulian apontou a importância que ambos, Heidegger e Lukács, atribuíam à vida cotidiana e ao fenômeno do estranhamento.

É justamente nesse diapasão que Sartori escreve Ontologia nos extremos: o embate Heidegger e Lukács, uma introdução. Ao levar em consideração o desenvolvimento das formulações lukácsianas diante e para além de Heidegger, Sartori projeta luz à importância que - filósofo alemão dá aos aspectos mais imediatos da sociedade civil-burguesa (bürgerliche Gesellschaft) enquanto procura seus fundamentos essenciais. Assim, é seguro afirmar que a bibliografia investigada por Sartori não se prende apenas a Para uma ontologia do ser social, no caso de Lukács, e a Ser e tempo, no caso de Heidegger. Ao contrário, a obra aqui resenhada enseja grande vulto quando cobre $A$ destruição da razão, $O$ jovem Hegel e a Estética, por um lado, e $O$ que é metafísica, Carta sobre o Humanismo, Introdução à Metafísica, $O$ Que é Isto, a Filosofia?, e Identidade e diferença, por outro.

Portanto a pesquisa de Sartori sustenta-se em um rastreamento da constituição das ontologias de Heidegger e Lukács, "tendo a compreensão do cotidiano e sua ligação com o fenômeno do estranhamento por parâmetro" (SARTORI, 2019, p. 16). Isso, é claro, reconhecendo os méritos e as críticas que Lukács tece diretamente a Heidegger enquanto mantém a lucidez de assumir a falta de reciprocidade do filósofo alemão nesse aspecto. Assim, Sartori rejeita "um trabalho filológico que busque ligar um autor ao outro" (SARTORI,
2019, p. 18) em detrimento da "importância da questão do estranhamento para os rumos dos debates filosóficos do século XX" (SARTORI, 2019, p. 20) evidenciada por Lukács, o que afasta Ontologia nos extremos: o embate Heidegger e Lukács, uma introdução das análises de Goldmann e o aproxima, em certo sentido, da concepção de Nicolas Tertulian, a qual identifica pontos que unem Heidegger a Lukács ao mesmo tempo em que os afasta.

Assim, conclui Sartori:

Deste modo, neste escrito, deve-se justamente mostrar o caminho que ambos os autores, Lukács e Heidegger, percorrem para que o estranhamento possa parecer-lhes como tema central à modernidade e ao homem moderno. Aqui, pois, não se busca saber se Heidegger se inspirou em Lukács ou tentou uma resposta à História e consciência de classe em Ser e tempo. Também não se procura saber o que da obra do autor alemão está na obra tardia do marxista. $O$ essencial nesse escrito é ver como o estranhamento, uma questão essencial aos rumos de nossa época, imediatamente posterior àquela dos autores aqui estudados, é visto de maneira, ao mesmo tempo, convergente e divergente nesses dois importantes pensadores do século XX (SARTORI, 2019, p. 21).

Feitas tais aduções, cabe aqui justificar a exposição da presente resenha. Dada a própria forma pela qual Sartori organiza Ontologia nos extremos: o embate Heidegger e Lukács, uma introdução, a saber, em duas grandes partes, neste texto será respeitado o arranjo original. $A$ primeira parte da obra, na qual são "tratados Heidegger e Lukács em consonância com o modo como dialogam com a filosofia precedente, tendo-se de um lado o 'passo de volta' (Schritt zurück) e doutro a busca de uma superação (Aufhebung)" (SARTORI, 2019, p. 23), será analisada logo abaixo. A segunda parte, que procura "demonstrar como a história, a ontologia e a técnica aparecem nesses dois importantes autores do século XX relacionadas, sobretudo, à problemática do trabalho, do estranhamento e da práxis transformadora" (SARTORI, 2019, p. 23), há de ser coberta na sequência.

Ainda se deve dizer que, devido à densidade e à extensão de Ontologia nos extremos: 0 embate Heidegger e Lukács, uma introdução, não passaria de mero devaneio ou de simples presunção anunciar o esgotamento dos temas cuidadosamente investigados e expostos por Sartori em uma resenha. Antes, este texto tem por objetivo a apresentação da obra e, como mencionado em momento anterior, sobrevoar as principais descobertas de Sartori. Portanto, pousar-se-á de modo mais enfático nas diferenças específicas entre Heidegger e Lukács no que toca ao posicionamento de ambos 
diante da filosofia precedente, em um primeiro momento, e, posteriormente, à concepção ontológica própria dos dois autores, assim instigando - se bem-sucedido - os interlocutores a conhecer os escritos de Sartori em questão por suas próprias palavras.

Acerca da "Parte I: Heidegger, Lukács, a ontologia e o diálogo com a filosofia precedente"

Como o título anuncia, a primeira parte do livro de Sartori volta-se aos diálogos que ambos os autores em tela estabelecem com a filosofia precedente. Se, por um lado, Lukács aparece "com uma postura que valoriza a tradição moderna da filosofia e principalmente a filosofia clássica alemã, buscando a superação da mesma" (SARTORI, 2019, p. 25), Heidegger, por outro, deseja "um 'passo de volta' em relação às questões levantadas de modo moderno, o que significaria remeter para algo além da filosofia moderna: tem-se uma virada (Khere)" (SARTORI, 2019, p. 25). Desde já, duas coisas tornam-se bastante claras a todos: a) tanto Heidegger quanto Lukács firmam diálogo com a filosofia moderna para gestar suas teorizações, ou seja, ambos versam sobre um objeto de certa forma comum; e b) é impossível reduzir um autor ao outro, tendo em vista que o posicionamento de cada um deles diante da modernidade é extremamente distinto. Aqui, pois, chama a atenção a proposta de Sartori, acima descrita e muito bem justificada pelos próprios traçados determinativos dos escritos por ele investigados.

De tal diferença específica, entretanto, cabe derivar breve aprofundamento a fim de ilustrar aos interlocutores da presente resenha aquilo do que dispõe Ontologia nos extremos: 0 embate Heidegger e Lukács, uma introdução. Há de se começar por Lukács, pois Sartori chama a atenção para a necessidade de se tratar do autor que enxerga algo de proveitoso na filosofia moderna e, por conta disso, sustenta a necessidade de superá-la (Aufhebung). Isso porque as bases daquilo que virá a ser criticado por Heidegger posteriormente já estariam lançadas ao leitor no momento em que se iniciasse $o$ rastreio dos textos do teórico alemão.

Sartori inicia a sua argumentação trazendo à baila a oposição entre o posicionamento lukácsiano e o marxismo vulgar, isto é, o stalinismo. Demonstra, pela própria palavra de Lukács, que a tendência stalinista é a de sistematizar e esquematizar a filosofia, resultando na tese de que o marxismo em si constituiria uma ruptura a-histórica com o pensamento pretérito. Esforço tal que enxerga "a teoria de Marx, e depois o marxismo, como um modo de pensar separado - por uma espécie de muralha - da filosofia e do pensamento precedentes" (SARTORI, 2019, p. 28).

Para Lukács, porém, afirma Sartori:

Longe de ter havido um "grande salto" para fora da história, e da história da filosofia em particular, um salto que trouxesse consigo algo absolutamente sem precedentes, haveria relativa continuidade do marxismo em relação ao "bimilenar desenvolvimento europeu", principalmente no que diz respeito aos "valores" trazidos com esse. Nisso, a justa apreensão das relações sociais é essencial à filosofia, a qual acompanha, inclusive, aquilo de mais digno na cultura ocidental, como o humanismo (SARTORI, 2019, p. 29)

Portanto, reitera o autor de Ontologia nos extremos, de acordo Lukács não há espaços para se conceber a relação entre Marx e a filosofia precedente na forma de um "corte" ou cisão, o que por si só afasta o teórico húngaro não apenas do marxismo vulgar como também de autores quais Louis Althusser. Contudo, não haveria em Marx uma continuidade pura e simples, que conservaria os elementos pretéritos indistintamente; antes, tratar-se-ia de uma "continuidade que dá lugar à emergência de um pensamento distinto, que traz consigo algo novo, mas que não é algo absolutamente separado daquilo que o precedeu. Tem-se uma 'superação"' (SARTORI, 2019, p. 30). Assim, a superação (Aufhebung) da qual fala Lukács é indissociável da percepção de que "a teoria de Marx é herdeira da tradição do humanismo, e mesmo da filosofia clássica alemã, ao mesmo tempo que, sem estabelecer cisões bruscas e abruptas com as conquistas pregressas, ultrapassa e transforma as mesmas de modo substancial" (SARTORI, 2019, p. 30).

Em outras palavras, Lukács compreende que a teoria de Marx se enquadra no longo itinerário de busca pela emancipação humana, caminho este no qual se destacam rupturas e continuidades. $\mathrm{O}$ grande mérito da filosofia precedente estaria, pois, no estabelecimento e na sustentação da sociedade civil-burguesa (bürgerliche Gesellschaft), progresso inegável diante da sociedade feudal. Contudo, dada a natureza classista da sociedade civil-burguesa (bürgerliche Gesellschaft), quando esta se vê de fato consumada, torna-se inviável a continuação do já mencionado itinerário emancipatório. A teoria de Marx, portanto, apresenta-se como superação (Aufhebung) na medida em que questiona $\circ$ ser-propriamente-assim das sociedades classistas, identificando os limites intrínsecos ao capital e a todo um rol de estranhamentos (Entfremdung) que coloca a subjetividade, tanto no espectro teórico quanto no prático, em uma condição limitada de 
passividade - o que está intimamente vinculado, inclusive, à imposição do caráter de incognoscibilidade da objetividade mesma.

Sobre o diálogo de Lukács com a filosofia precedente, conclui Sartori:

\begin{abstract}
No que se vê: o modo como Lukács enxerga as filosofias anteriores liga-se ao tempo em que elas se desenvolvem e depois são efetivas - trata-se, pois, de se ver o pensamento precedente em meio às contradições concretas que marcam uma época e, em se tratando da filosofia moderna, pode-se mesmo dizer, a época capitalista. Hegel, por exemplo, seria indissociável da Revolução Francesa e da consolidação da sociedade civil-burguesa, ao passo que Marx precisaria superar (aufheben) tal ponto de partida. $E$ isso teria implicações substantivas para a teoria do autor de $O$ capital, também no que diz respeito à questão do estranhamento, a qual será combatida pelo autor justamente com sua posição socialista, contrária à própria manutenção do capitalismo como tal. Com isso, agora, podese dizer que, para o marxista húngaro, a forma de diálogo com a filosofia precedente é aquela da superação, da supressão. E Heidegger (tal qual Althusser) vai se opor explicitamente a esse modo de se relacionar com o passado (SARTORI, 2019, p. 34).
\end{abstract}

Contudo, antes de passar a Heidegger, Sartori ainda alerta seus leitores sobre o sentido materialista de superação (Aufhebung) tanto em Marx quanto em Lukács. Diferentemente da colocação hegeliana do problema, que se baseia na premissa do sujeitoobjeto idêntico para criar um vínculo lógico entre o desenvolvimento da realidade efetiva (Wirklichkeit) e o desenvolvimento do Espírito (Geist) - em que "o verdadeiro é o vir-a-ser de si mesmo" (HEGEL, 2014, p. 32), isto é, em que a superação (Aufhebung) coloca-se como elemento lógico e necessário do desenvolvimento presumidamente racional da realidade mesma -, em Marx e, consequentemente, em Lukács, a superação (Aufhebung) possui caráter concreto, ou seja, é indissociada da resolução real de contradições reais que estão presentes na realidade efetiva (Wirklichkeit) mesma. Em outras palavras, o problema da superação (Aufhebung) em Marx e Lukács não depende de uma questão metodológica - se por método considerar-se um arranjo a priori das faculdades cognitivas humanas, um esforço de cunho gnosiológico que se pergunta sobre as possibilidades e condições do conhecimento antes mesmo de se entrar em contato com o objeto a ser conhecido - ou da mera especulação, que, por sua vez, autonomiza a razão (Vernunft) e a coloca no status de demiurgo do real.

A questão da superação (Aufhebung), tanto em Marx quanto em Lukács, se trazido à tona o problema do estranhamento (Entfremdung) - o que é fundamental para Sartori -, significa a supressão prática da sociedade capitalista. A partir do momento em que Marx critica a natureza classista da sociedade civil-burguesa (bürgerliche Gesellschaft), visando superá-la, coloca-se também em xeque todos os seus predicados que se apresentam como forças sobre-humanas e dominadoras dos indivíduos. Ou seja, a condição de superação dos estranhamentos jaz na superação da própria sociedade que os engendra. Nesse sentido, a já mencionada continuidade constitutiva do diálogo de Lukács com a filosofia precedente está na continuidade do debate "com as contradições que percorrem a própria história, na modernidade, marcada primeiramente pela emergência, e depois pela crise, do capital, o que é inseparável da temática do estranhamento" (SARTORI, 2019, p. 39).

Ainda nessa toada, afirma Sartori:

Os rumos da filosofia são inseparáveis dos rumos da história, sendo que há nos grandes pensadores de um tempo uma posição concreta quanto às questões fundamentais de suas épocas. Uma superação efetiva, pois, tem consigo uma posição distinta daquela da filosofia que a precede [...] O modo como se dialoga com a filosofia, assim, traz uma posição concreta (Standpunkt) que busca não só melhor compreender uma época, mas também transformá-la - até mesmo porque, para Lukács, na própria transformação da realidade é que melhor se compreende a mesma (SARTORI, 2019, p. 39).

Heidegger, por sua vez, traça um diálogo bastante distinto com a filosofia precedente. No autor alemão é patente a crítica do progresso, uma vez que, para ele, tal noção é indissociável de um pensamento conceitual, ou seja, do idealismo moderno inaugurado por Descartes. Segundo Heidegger, o pensamento conceitual estaria embebido de uma compreensão que confere ao ser humano a qualidade de animal racional e de uma centralidade da lógica. A essa forma de pensar Heidegger atribui o status de ontologia tradicional, em um primeiro momento, e de metafísica, posteriormente. Portanto, logo de início conclui-se que, para o filósofo alemão, a modernidade possui uma dimensão negativa que a impede de ser tomada como parâmetro fulcral - em verdade, faz-se necessário romper de uma vez por todas com esse pensamento conceitual, o que resulta em uma ontologia fenomenológica que busca na filosofia clássica, em especial em autores como Platão, Aristóteles e nos assim chamados présocráticos, a abertura para se pensar as questões originárias. Nisso consiste o "passo de volta" (Schritt zurück): "Trata-se de um 'outro começo"” (SARTORI, 2019, p. 42).

Diante disso, Sartori aponta para uma 
questão fundamental: se em Heidegger há o repúdio da modernidade, do progresso e da lógica, em suma, do pensamento conceitualque atribui ao ser humano a qualidade de animal racional e tem consigo a centralidade da verdade absoluta, não se pode olvidar as críticas de Heidegger a Hegel, autor que elevou a lógica à condição de ciência - basta lembrar de um dos títulos mais importante do antigo reitor da Universidade de Berlim, A ciência da lógica. Portanto, mesmo que de maneira sumária, Sartori se debruça sobre o tema e extrai o seguinte:

A filosofia heideggeriana coloca-se de modo crítico diante do apelo de Hegel ao absoluto e ao incondicionado, dizendo ser a filosofia hegeliana uma "ontoteologia", dado que ela pensaria nos termos da ontologia medieval (tradicional) e apelaria, mesmo com inúmeras mediações, à noção segundo a qual "Deus é a verdade, e só ele é a verdade". Critica-se a noção hegeliana quando teria ela como pressuposto uma "reconciliação" (Vörsonung) em que a ideia apareça dando um télos ao processo que, por sua vez, ao fim, teria reconciliados o sujeito e o objeto, idealidade e realidade, em uma identidade especulativa (SARTORI, 2019, p. 43).

Assim, apesar de semelhantes em aparência, as críticas de Heidegger e de Lukács à filosofia hegeliana guardam diferenças substanciais. Enquanto Lukács identifica em Hegel a excelência teórica da sociedade civil-burguesa (bürgerliche Gesellschaft) e, por isso mesmo, a condição de pensamento limitado frente à essência das contradições efetivas, que pensa estarem solvidas por determinados predicados do próprio pensamento, o que leva o filósofo húngaro à necessidade de superação (Aufhebung) concreta e consciente da sociedade capitalista, como visto acima, Heidegger identifica em Hegel a negatividade dos tempos modernos, o império da metafísica, a condição que relega aos indivíduos a incapacidade de se tematizar a essência da verdade, uma vez que ela - a verdade - se encontra hipostasiada naquilo de superado no absoluto, ou seja, esquecida. E é justamente por conta dessa dimensão de esquecimento da verdade, que jaz indissociada da modernidade, da lógica e do modo de pensar metafísico, que Heidegger defende o "passo de volta" (Schritt zurück), um novo começo.

Heidegger, portanto, tem o intuito de escapar da filosofia precedente, isto é, do modo de pensar metafísico, recorrendo a um esforço intelectivo que não se veja limitado pelo princípio da identidade que apaga as diferenças específicas mediante um juízo lógico e, então, deixa a essência da verdade oculta e impensada. "Tratar-se-ia, em Heidegger, primeiramente, de se pensar aquilo que é mais digno e que escapa ao logos moderno: o fato de que, sem se pensar o Ser concretamente, este passaria a ser visto como ratio, razão, inclusive no sentido matemático" (SARTORI, 2019, p. 46).

Contudo, como aponta Sartori, a busca pelo novo começo sob a ótica do "passo de volta" (Schritt zurück) não impediu Heidegger de tomar uma posição efetiva diante da realidade em que vivia. Apesar da compreensão de que a modernidade é inautêntica - e, portanto, também o seria o cotidiano moderno -, Heidegger ainda vê aberturas para a autenticidade na medida em que a sua proposta fenomenológica tem por central o desvelar do poder-ser (sein können).

É assim que se desenvolve o acontecimento (Ereigniz), como diz Sartori:

\begin{abstract}
Em meio à inautenticidade (Uneigentlichkeit) moderna e cotidiana, ela só pode aparecer como algo extraordinário, como um acontecimento (Ereigniz) - a essência da verdade não poderia ser vista pela certeza e pela adequação. Diz-se assim: "o essenciar-se do Ser mesmo; o chamamos de acontecimento" (SARTORI, 2019, p. 46-47).
\end{abstract}

Mas por que o acontecimento (Ereigniz) só pode aparecer como algo extraordinário? Ora, justamente porque a cotidianidade dos tempos modernos é marcada pela indistinção, pela dissolução das diferenças pessoais naquilo que Heidegger chamou de impessoal (das Mann). E o impessoal ressoa no pensamento conceitual, na metafísica, a partir do princípio da indiferença, na noção de verdade como certeza, como verdade posta e inquestionável. A essência da verdade, o mais digno de ser pensado, jaz oculta na própria cotidianidade dos tempos modernos devido à indistinção dos diversos indivíduos que a compõem no impessoal (das Mann) - o que guarda relação fundamental com o fenômeno do estranhamento - e, portanto, ressoa como impossibilidade de tematização no modo de pensar metafísico, na concepção de progresso que se encontra, como visto anteriormente, na noção hegeliana de superação (Aufhebung) em que impera a máxima do pensamento que pensa a si mesmo. Portanto, para Heidegger, a metafísica perpetua o estranhamento sob a noção de verdade como certeza, mantendo-se na qualidade de forma de pensar inautêntica sobre um modo de vida também inautêntico: a própria cotidianidade dos tempos modernos.

A fim de ilustrar essa explicação, traz-se Sartori:

Com isso, o homem, trivialmente, apareceria sufocado num convívio que exprime não os anseios condizentes com seu poder-ser (sein können), mas com um perder-se em meio aos entes que, por seu turno, se mostram como 
indiferenciados. Há, para Heidegger, uma situação em que cada um é com o outro só de modo impessoal e inautêntico: trata-se de uma perda de si (Verlorenheit), a qual Heidegger relaciona justamente com 0 estranhamento (SARTORI, 2019, p. 48)

É nesse sentido que 0 acontecimento (Ereigniz) só pode aparecer como algo extraordinário. Tendo em vista o predomínio do impessoal (das Mann) na cotidianidade dos tempos modernos e as noções de verdade como certeza e adequação trazidas pela metafísica, há o esquecimento do Ser em duas frentes: a) na cotidianidade, em que cada um só é com o outro de forma impessoal, inautêntica - onde todos os entes se mostram de maneira indiferenciada, configurando uma perda de si dos indivíduos; e b) na filosofia, isto é, na metafísica, que leva o impessoal (das Mann) ao plano do pensamento sob um juízo lógico capaz de apagar as diferenças e, assim, formular uma verdade inquestionável porque acabada, ou seja, suprassumida como racionalidade do processo progressivo. E, para Heidegger, esse esquecimento do Ser sob o jugo do impessoal (das Mann) pode, nas últimas consequências, desenvolver-se como ditadura da opinião pública (Diktatur der Öffentlichkeit).

Sobre a relação indissociável entre 0 esquecimento do Ser e o estranhamento, bem como acerca da metafísica enquanto forma de pensar que perpetua ambos os elementos e da necessidade do "passo de volta" (Schritt zurück) para de todo esse emaranhado se livrar, diz Sartori:

O "esquecimento do Ser" tem consigo, pois, o estranhamento, sendo a metafísica o modo pelo qual o pensar é equacionado de maneira técnica, ao ponto de o particularismo dos "ismos", criticado pelo autor, se impor na cotidianidade de modo evidente, no entanto, "ditatorial". O "passo de volta" heideggeriano, pois, busca certo distanciamento em relação à modernidade e procura re-pensar (er-denken) aspectos esquecidos desde os gregos; só assim seria possível uma filosofia, não mais moderna e, como tal, para Heidegger, marcada pelo esquecimento e pelo estranhamento (SARTORI, 2019, p. 50).

Porém, como muito bem direciona Sartori, o "passo de volta" (Schritt zurück) heideggeriano não se resume a uma simples nostalgia do passado, a uma recusa impetuosa do presente. Ao adotar um princípio fenomenológico, Heidegger assume que a cotidianidade dos tempos modernos e a metafísica, mesmo sendo marcadas pelo esquecimento do Ser e pelo estranhamento, preparam o impensado. Em outras palavras, para se atingir aquilo digno de ser pensado é preciso partir da modernidade; mas partir da modernidade de um modo bastante específico, como visto anteriormente, mediante um afastamento das certezas impostas pela cotidianidade dos tempos modernos e pela metafísica, isto é, por meio do "passo de volta" (Schritt zurück), que permite o re-pensar (er-denken) e, assim, alcançar o fundamento (Grund) - este intimamente relacionamento a elementos esquecidos pela modernidade, como a temporalidade (Zeitlichkeit) e a historicidade (Geschichtlichkeit). Portanto, em Heidegger há uma busca constante pelo "passo de volta" (Schritt zurück) em detrimento da superação porque, enquanto aquele tem a potencialidade de descobriro fundamento (Grund), esta apenas relega a essência do Ser ao esquecimento, configurando-a como certeza e adequação.

Nesse sentido, o "passo de volta" (Schritt zurück) é indissociável do acontecimento (Ereigniz). Isso se explica porque a própria atitude de se recuar diante do já pensado a fim de escapar das balizas da cotidianidade e da metafísica permite o descobrimento do fundamento (Grund). Em outras palavras, é mediante o "passo de volta" (Schritt zurück) que se atinge os elementos originários concernentes ao Ser, transcendendo o plano ôntico e livrando-se do estranhamento e do domínio do impessoal (das Mann) tanto na cotidianidade quanto na metafísica modernas. O próprio ato de pensar de maneira fenomenológica é, pois, um acontecimento (Ereigniz), já que guarda em si algo de extraordinário, a saber, a possibilidade de abertura para o descobrimento, para a transcendência do plano ôntico em sentido ao ontológico.

Ainda no tocante ao "passo de volta" (Schritt zurück), é importante ressaltar, como faz Sartori, que o esforço heideggeriano, assim como a perspectiva da superação (Aufhebung) em Marx e Lukács, não se reduz a uma questão de método. Para Heidegger, o descobrimento do impensado por meio da posição fenomenológica só se dá durante o passo mesmo, quando ocorre o desvelar da essência - este não concebido de início, por uma faculdade racional a priori ou autônoma, mas descoberto no sentido de desvelamento ou ainda de desencobrimento.

Comprovando os comentários, diz Sartori:

Para o autor de Ser e tempo, a via para a ontologia - e para a crítica ao estranhamento - está na fenomenologia nesta acepção aqui vista. A tradição, a filosofia precedente não seria, pois, só um "passado", mas um "passado-presente", o qual, mesmo com as vicissitudes modernas, poderia oferecer a abertura fenomenológica para o mais originário, ainda impensado. Só em meio ao esquecimento daquilo mais importante seria possível se conceber o descobrimento, o qual 
não teria consigo algum sentido prévio, como na superação hegeliana, mas somente um deixar-ser no qual "o 'para-onde' ao qual conduz o passo de volta somente se desenvolve e se mostra, através do exercício do passo". Ou seja, não se trata de um movimento em que a essência aparece a partir da existência, manifestando tal processo o essencial presente no télos dado pela própria razão (Vernunft) - o caminho do pensar heideggeriano só se formaria no caminhar, devendo-se ver o solo desse "não como ratio, não como causa primordial, não como fundamento racional, mas como um deixar existir concretamente". E isso é essencial (SARTORI, 2019, p. 55).

Portanto, faz-se clara não só as distinções entre os diálogos firmados por Heidegger e Lukács com a filosofia precedente, mas também as diferenças fundamentais no que toca ao posicionamento concreto de ambos os autores diante do estranhamento. Enquanto Lukács, seguindo o diapasão marxiano, busca a superação dos estranhamentos por meio da prática revolucionária e transformadora da realidade mesma - condição de existência dessas forças alheias aos indivíduos -, Heidegger agarra-se à fenomenologia para vislumbrar possibilidades de descobrir o fundamento (Grund), transcender o plano ôntico e, portanto, livrar-se do estranhamento intrínseco à cotidianidade dos tempos modernos e à metafísica.

Acerca da "Parte II: Trabalho, história e técnica: ontologia do ser social e ontologia fenomenológica"

Como anuncia Sartori, a segunda parte de Ontologia nos extremos: o embate Heidegger e Lukács, uma introdução volta-se à forma pela qual a ontologia do ser social de Lukács empreende uma crítica ao trabalho abstrato a partir da categoria marxiana de trabalho concreto, por um lado, e ao modo como Heidegger, em sua ontologia fenomenológica, tece uma crítica à técnica apoiada sobre a noção de acontecimento (Ereigniz), por outro. Diante disso, Sartori acaba por ocupar-se também, de maneira imanente, da concepção de historicidade heideggeriana e da noção lukácsiana de história. Tudo sem perder de vista a matéria do estranhamento, que, como já foi tratado acima, é fundamental quando os dois autores são colocados em tela.

Sartori inicia a sua argumentação trazendo à baila o desenvolvimento lukácsiano da relação entre trabalho e estranhamento, partindo da autocrítica realizada pelo próprio filósofo húngaro, em 1967, ao livro História e consciência de classe, publicado por ele em 1923. A importância da questão logo é revelada: se, em 1923, Lukács não se atentou ao ser-propriamente-assim do ser social devido a limitações pessoais, opondo à contemplação neokantista uma noção de práxis que pairava no ar, decerto não conseguiu superar, naquele momento, a tese hegeliana do sujeito-objeto idêntico. Esse fato, como reconhecido pelo próprio Lukács em 1967, resultou na confusão entre toda forma de objetivação e a categoria de estranhamento (Entfremdung), o que acabou por fazer o filósofo húngaro apenas se alojar no interior da reflexão idealista, a qual ele almejava criticar. Pior: de acordo com Sartori, acertadamente, o Lukács de 1923 ainda enxergava "a práxis social como essencialmente estranha ao controle consciente, sendo tanto os meios como os produtos do trabalho algo que se volta contra a realização da humanidade do trabalhador" (SARTORI, 2019, p. 106).

\begin{abstract}
Tal concepção só viria a ser superada por Lukács em sua obra madura, a partir da investigação necessária e cuidadosa da teoria marxiana. Feita a sua guinada rumo ao materialismo, o filósofo húngaro concluiu, agora corretamente, que a objetivação é uma consequência natural da atividade humana no mundo, enquanto o estranhamento (Entfremdung) configura-se como um tipo negativo de objetivação, cuja gestação e atuação dependem de condições sociais específicas. Em outras palavras, "a objetivação e a alienação concatenam-se no processo pelo qual o homem produz um ente, [...] mas se tal objetividade [...] coloca-se ou não contra o desenvolvimento humano, isso diz respeito às circunstâncias sociais" (SARTORI, 2019, p. 108).
\end{abstract}

Sartori ainda evidencia outro aspecto importantíssimo acerca da matéria. A ausência da apreensão do ser-propriamente-assim do ser social, isto é, a recusa - consciente ou não - do materialismo marxiano, obscurece a historicidade do ser social porque toma o estranhamento (Entfremdung) como qualidade intrínseca à relação do homem no e para com o mundo. Mesmo em um autor do vulto de Hegel, que despende grande atenção à história e busca resolver o problema do estranhamento, acaba resolvendo a questão de modo insatisfatório, pois, na toada de que a filosofia é o pensamento que pensa a si próprio, dilui o revés no seio do pensamento e contenta-se com uma resposta especulativa, que não implica na transformação das condições pelas quais o estranhamento se engendra.

Resume Sartori:

[...] para Hegel, se a filosofia, tomando como supostas essas circunstâncias, quer superar o estranhamento, deveria rumar ao absoluto, e somente lá o estranhamento poderia ser superado com base na "reconciliação" das contradições desenvolvidas no espírito objetivo e suspensas no absoluto. Com isso, 
as próprias relações sociais concretas (expressas no espírito objetivo), não só vêm a deixar de construir o essencial quando se trata de superar o estranhamento. A superação do estranhamento se dá ao custo da mistificação da realidade objetiva, que passa a ser, sob este aspecto, um mero momento da realização - marcadamente teleológica - do espírito absoluto (SARTORI, 2019, p. 109).

Diante do exposto é que se pode aferir o caráter materialista e histórico da ontologia do ser social lukácsiana. Seguindo o itinerário marxiano, Lukács compreende o ser como entificação concreta, complexo de determinações objetivas que existe independentemente da consciência e que, a partir da emergência da subjetividade, constitui-se em uma relação indissociável com ela. Há, pois, uma autarquia relativa da realidade objetiva sobre as formas de consciência. Autarquia porque "as categorias expressam formas de ser, determinações de existência" (MARX, 2016, p. 59), isto é, partes constitutivas de uma objetividade externa aos indivíduos e que se impõem sobre eles, interferindo efetivamente em seu campo de possibilidades de ação; relativa porque a relação dos homens no e para com o mundo não somente é inalienável para a manutenção da vida humana, mas também porque mediante a sua atividade altera-se de modo concreto a própria objetividade. Para Lukács, a ontologia é, portanto, "a modalidade real e concreta da existência do ser, a sua estrutura e movimento" (NETTO, 1978, p. 70).

Ou ainda, como diz Sartori:

[...] em Lukács, quando se trata de conjunto de "todo o existente" e do ser, percebe-se que se busca uma apreensão adequada da realidade social, a qual teria consigo determinações históricas e objetivas, tratando-se sempre não de um ente apreendido imediatamente, mas do processo pelo qual as determinações do ser se desenvolvem (SARTORI, 2019, p. 117).

Heidegger, por sua vez, apresenta uma concepção ontológica muito distinta da de Lukács. De rompante, já é possível dizer que o filósofo alemão rechaça a concepção de Marx, também integrada às formulações lukácsianas, de que "as categorias expressam formas de ser, determinações de existência" (MARX, 2016, p. 59). Uma vez que, como levantado na seção anterior, o próprio estranhamento é, para Heidegger, indissociável da perda de si diante da indiferenciação do mundo, qualquer esforço intelectivo que almeje a apreensão do serpropriamente-assim da realidade objetiva cairia nos limites intrínsecos à cotidianidade e, portanto, sucumbiria ao império do impessoal (das Mann).

\section{A esse respeito, esclarece Sartori:}

O modo como o homem se relaciona com o mundo tendo por base a última seria essencialmente agressivo, dominador - e, como visto, isso teria deixado resquícios em Hegel, Marx e, seguindo o pensamento heideggeriano, Lukács. A noção de adequação criticada pelo autor de $\operatorname{Ser} e$ tempo traria consigo não só a impossibilidade de se pensar aquilo de mais digno, "isso determina para o futuro como uma consequência da nova transformação da essência da verdade, o caráter tecnológico do moderno, isso é, da técnica da máquina". Se o autor da Ontologia do ser social busca o ser-propriamente-assim da objetividade, a percepção correta da realidade objetiva, tratar-se-ia, em verdade, seguindo o autor de Ser e tempo, de uma "ontologia tradicional" (SARTORI, 2019, p. 118)

Para Heidegger, o próprio esforço intelectivo de se buscar uma verdade objetiva está atado aos limites da metafísica e da cotidianidade dos tempos modernos. Tratar-seia, antes, de adotar a postura do "passo de volta" (Schritt zurück) para re-pensar (erdenken) a constituição do homem no mundo, que subjaz à própria objetividade do real, constituindo-se como elemento originário, e, assim, buscar descobrir o fundamento (Grund). Fundamento (Grund) este, como visto na seção anterior, que não é base racional ou resposta aos moldes do pensamento conceitual, mas o próprio caminho de se desvelar, desencobrir, os fenômenos.

Assim, estaria colocada a ontologia fenomenológica de Heidegger. Fenomenologia justamente porque parte dos fenômenos da cotidianidade dos tempos modernos a fim de se atentar para a forma pela qual eles mesmos se mostram, não em busca de uma lógica ou razão de ser desses fenômenos, mas antes da transcendência que se poderia alcançar ao ter como enfoque as questões originárias. Em outras palavras, a objetividade enquanto objetividade seria inessencial à teorização heideggeriana, pois as coisas não constituem por si mesmas objetos. A questão central está no deixar-ser proposital, em manter-se aberto para aquilo de extraordinário, para um acontecimento (Ereigniz).

Contudo, até mesmo o enfoque na subjetividade, para Heidegger, está vinculado à cotidianidade dos tempos modernos e ao estranhamento engendrado pela "ditadura" do impessoal (das Mann) e pela metafísica. Pensar de acordo com a dicotomia entre sujeito e objeto, mesmo que de maneira indissociável, é um resquício do pensamento conceitual próprio da modernidade. Em outras palavras, é manterse atado ao plano ôntico, no qual jaz o estranhamento na indiferenciação do 
conglomerado de entes. O "passo de volta" (Schritt zurück), isto é, o esforço intelectivo de se re-pensar (er-denken) as questões originárias, o fundamento (Grund), liberta-se do logicismo que impregna o plano ôntico com a noção de que o ser humano é um animal racional enquanto mantém-se aberto para um acontecimento (Ereigniz). Assim, para Heidegger, haveria a transcendência para 0 plano ontológico.

Sobre o exposto, diz Sartori:

\begin{abstract}
A "universalidade" do Ser, portanto, não está na indeterminação como em Hegel, nem na objetividade e na historicidade, como quer Lukács - a questão do Ser traria consigo, em Heidegger, um remeter para além, como visto, "o ser e a sua estrutura ontológica se acham acima de qualquer ente e de toda determinação ôntica possível de um ente". Se "o ser é o transcendens pura e simplesmente", isso advém de a ontologia heideggeriana não tratar da realidade objetiva ao modo de um Lukács, o qual, assim, permaneceria - seguindo o autor de Ser e tempo - na busca de determinações ônticas dos entes ao modo da ontologia tradicional, da "metafísica". Heidegger busca ultrapassar a determinação ôntica remetendo para a ontologia, ele visa, pois, àquilo que chama de verdade do "sentido do Ser" e não à dominação do mundo dos entes, embora seja preciso se partir do modo como os próprios entes se mostram primariamente enquanto fenômenos. Portanto, se questiona o Ser do ente para que seja possível um além, um transcendens, partindo daquilo que se apresenta. A fenomenologia, neste sentido, configura-se como a abertura do Ser, como clareira (Lichtung), que, levaria a um percurso que se trilha no transcorrer dele mesmo, e que é, em si, veritas transcendentalis. $\mathrm{Na}$ fenomenologia heideggeriana não há muralha entre verdade empírica e transcendental - é da experiência privilegiada do ser-aí que emerge a possibilidade da transcendência (SARTORI, 2019, p. 123).
\end{abstract}

No grau de abstração que compete à presente resenha, resta no mínimo clara uma questão importantíssima: a diferença específica entre o tratamento dado à ontologia pelos dois autores em tela. Para Heidegger, há uma dicotomia central entre Ser e ente na qual este, o domínio ôntico, é marcado pela "ditadura" do impessoal (das Mann) e pelo estranhamento, enquanto aquele, o plano ontológico, transcendental, é alcançado mediante um "passo de volta" (Schritt zurück) que se desprende das questões pertinentes ao conglomerado dos entes para privilegiar as questões originárias. Para Lukács, a ontologia diz respeito ao modo de ser da realidade objetiva, bem como à sua estrutura e ao seu movimento, marcados pela historicidade e pela processualidade.
Tal oposição, contudo, como aponta Sartori ao embrenhar-se nas determinações concretas de ambas as teorias, não constitui mero debate de ideias que pairam no ar, subsistindo à míngua. Antes, revela dois extremos no que concerne à tomada de posição dos autores diante da realidade mesma. Lukács, qual ressaltado ao longo de todo o texto, assume um caráter revolucionário e aposta na atividade humana sensível como prática capaz de transformar a realidade objetiva, derrubando as bases que engendram o estranhamento e, consequentemente, a produção dos homens enquanto entrave para o próprio itinerário de hominização. Heidegger, por outro lado, deposita as suas fichas em uma configuração transcendental marcada pelas questões que foram esquecidas pela modernidade, relegando a mobilização radical ao plano do impertinente, pois o próprio tratamento das determinações presentes na sociedade civil-burguesa - fossem elas positivas ou negativas - é alienígena à filosofia.

É mediante o levantamento dessa problemática que se convida a ler Ontologia nos extremos: o embate Heidegger e Lukács, uma introdução. A partir da pesquisa levada a cabo por Sartori e da conformação dos embates filosóficos de nosso tempo - "tempo esse em que a herança de Heidegger parece ter vencido a batalha de ideias sobre a questão ontológica" (VAISMAN, 2019, p. 10) -, indaga-se: a mobilização de potências transformadoras do mundo é, de fato, algo sem mérito para as reflexões filosóficas? Mais vale um "passo de volta" diante do mar tempestuoso dos estranhamentos?

Referências bibliográficas

HEGEL, Georg Wilhelm Friedrich, Prefácio. In: HEGEL, Georg Wilhelm Friedrich. Fenomenologia do espírito. Petrópolis: Vozes, 2014.

MARX, Karl. Contribuição à crítica da economia política. São Paulo: Expressão Popular, 2017.

MARX, Karl. Grundrisse. São Paulo: Boitempo, 2016.

NETTO, José Paulo. Lukács e a crítica da filosofia burguesa. Lisboa: Seara Nova, 1978.

SARTORI, Vitor B. Ontologia nos extremos: o embate Heidegger e Lukács, uma introdução. São Paulo: Intermeios, 2019.

VAISMAN, Ester. Apresentação. In: SARTORI, Vitor B. Ontologia nos extremos: o embate Heidegger e Lukács, uma introdução. São Paulo: Intermeios, 2019, p. 7-10. 


\section{Como citar:}

HELENO, Matheus Correa de Sousa. A questão do estranhamento entre a superação e o passo de volta: sobre Ontologia nos extremos. Verinotio, Rio das Ostras, v. 27, n. 1, pp. 442-451, jan./jun 2021. 